\title{
Folic acid-modified diatrizoic acid-linked dendrimer- entrapped gold nanoparticles enable targeted CT imaging of human cervical cancer
}

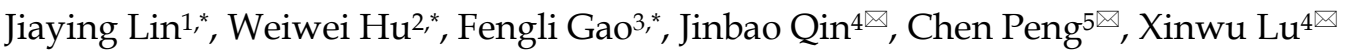 \\ 1. Department of Assisted Reproduction, Shanghai Ninth People's Hospital, Shanghai Jiao Tong University, School of Medicine, 639 Zhizaoju Road, Shanghai \\ 200011, China \\ 2. Department of Critical Care Medicine, the Affiliated Hospital of Xuzhou Medical University, Jiangsu, 2210021, PR China \\ 3. Department of Vascular Surgery, General Hospital of Ningxia Medical University, Ningxia, 750002, PR China \\ 4. Department of Vascular Surgery, Shanghai Ninth People's Hospital, Shanghai JiaoTong University, School of Medicine, Shanghai, 200011, PR China \\ 5. Department of Radiology, Shanghai Tenth People's Hospital, Tongii University School of Medicine, Shanghai, 200072, PR China \\ *Authors contributed equally to this work.
}

$\square$ Corresponding authors: E-mail: luxinwu@shsmu.edu.cn (X. Lu), jinbaoqin@163.com (J. Qin) and pengchen_1985@163.com (C. Peng). Xinwu Lu, Vascular Center of Shanghai JiaoTong University, Shanghai, 200011, PR China; Department of Radiology, Shanghai Tenth People's Hospital, Tongji University School of Medicine, Shanghai, 200072, PR China Tel:862123271699 Fax:862163136856

(C) Ivyspring International Publisher. This is an open access article distributed under the terms of the Creative Commons Attribution (CC BY-NC) license (https://creativecommons.org/licenses/by-nc/4.0/). See http://ivyspring.com/terms for full terms and conditions.

Received: 2017.02.23; Accepted: 2017.08.06; Published: 2018.01.01

\begin{abstract}
It has been a great challenge to develop multifunctional fluorescent nanoprobes for tumor-targeted imaging. In this study, we developed folic acid (FA) gold nanoparticles (AuNPs) through diatrozic acid (DTA) linking for in vitro and in vivo targeted imaging of HeLa cervical cancer cells by computed tomography (CT). G5 dendrimers were used as templates to synthesize AuNPs within the interiors of dendrimers. The synthesized AuNPs were then sequentially modified by fluorescein isothiocyanate, FA, and DTA and the remaining terminal amines on the dendrimers were acetylated. We further performed hematoxylin and eosin staining, cell viability assay, flow cytometric analysis of cell cycle and apoptosis, and hemolytic assay to examine the cytotoxicity and hemocompatibility of the particles. The specific uptake of the nanoparticles by HeLa cells was determined through inductively coupled plasma atomic emission spectroscopy determination of silver and transmission electron microscopy. Lastly, HeLa cells and a xenografted HeLa tumor model were employed to evaluate the in vitro and in vivo targeted CT imaging performances of the nanoparticles, respectively. We showed that $\mathrm{Au}$ DENPs-FA-DTA does not cause cytotoxic effects on both HeLa cancer cells and healthy normal cells in mice, demonstrating the superior biocompatibility and stability of the particles in the given concentration range. Micro-CT images documented that HeLa cells incubated with Au DENPs-FA-DTA in vitro could be identified by $X$-ray examinations and that HeLa cells xenografts in BALB/c nude mice could be imaged after the mice were administered with the particles intravenously or intratumorally. The FA-modified AuNPs enabled targeted CT imaging of HeLa cells overexpressing FA receptors in vitro and in vivo. Taken together, our results showed that the AuNPs we developed exhibit great potentials as imaging probes for targeted CT imaging of human cervical cancer.
\end{abstract}

Key words: Dendrimers; Gold nanoparticles; Computed tomography; Folic acid; Cervical cancer

\section{Introduction}

Cervical cancer is one of the most common female reproductive tract diseases and the leading causes of death in females worldwide (1). When cervical cancer is detected at the early or preinvasive stages, it can be treated by surgical resection combined with standard concurrent chemotherapy and radiotherapy. Unfortunately, a substantial proportion of patients with invasive cervical cancer still suffer relapses or the cancer may progress into more advanced stages after the initial treatment. Thus, the development of novel and effective approaches to treat the disease remains a priority (2). Current therapies against human cervical cancer, including chemotherapy and radiation therapy, are not highly 
specific to cancer cells and can kill both normal and cancer cells, which considerably limits their therapeutic potentials. Importantly, recent findings in the field of nanotechnology can potentially revolutionize multiple aspects of cervical cancer diagnosis and treatment (3-5).

Substantial research effort has been made to develop nanoparticle (NP) systems that can selectively target and eliminate cancer cells at an early stage. Among these systems, Au gold nanoparticles (AuNPs) have been shown to be one of the most promising technologies for the targeted imaging and treatment of cancer cells (6-10). Firstly, Au has a higher atomic number and electron density and exhibits a higher X-ray attenuation intensity than iodine, thereby considerably improving the contrast enhancement in CT imaging. Secondly, AuNPs are not cytotoxic within a certain range of concentrations (11). Thirdly, they can be easily conjugated with chemical moieties such as targeting agents, imaging dyes, or specific biomarkers (12). Lastly, the conjugation of AuNPs to appropriate surface ligands can help to reduce the clearance of the nanoparticles via the reticuloendothelial system (RES) of the human body and prolong their circulation time in the bloodstream (13). Furthermore, AuNPs can penetrate the leaky tumor vasculatures and preferentially accumulate in tumor cells through the enhanced permeation and retention (EPR) effects of the tumor tissue, thereby improving the specificity and sensitivity of cancer imaging (14).

Dendrimers are a class of repetitively branched macromolecules that adopts a spherical three-dimensional architecture with a large number of reactive end groups (15-17). The exceptional physicochemical properties of dendrimers have enabled them to be widely used to synthesize AuNPs (18-20). Dendrimers can be constructed to display different molecular weights and chemical compositions that facilitates the attachment of a variety of imaging reagents or therapeutic drugs (21). Moreover, the remaining amine groups of dendrimers can further be modified by acetylation to shield the positive potential of the dendrimers, thereby preventing nonspecific binding of the nanoparticles to human tissues and reducing undesirable side effects (18). Our previous studies have demonstrated that $\mathrm{Au}$ dendrimer-encapsulated NPs (DENPs) or $\mathrm{Au}$ dendrimer-stabilized NPs (DSNPs) can be covalently bound to targeting molecules for specific targeting of human cancer cells (22-23). These findings suggest that it is feasible to perform targeted CT imaging of human cancer cells using acetylated Au DENPs whose surface is modified with targeting molecules.
In the present study, folic acid (FA)- and fluorescein isothiocyanate (FI)-modified G5 dendrimers were complexed with tetrachloroauric acid trihydrate $\left(\mathrm{HAuCl}_{4}\right)$. The terminal amines of the dendrimers were then modified by acetylation to generate the multifunctional $\mathrm{Au}$ DENPs using a single-step reaction at room temperature (Scheme 1). After AuNPs was entrapped into the interiors of the PEGylated dendrimers, a further acetylation reaction was performed to neutralize the remaining terminal amines of the dendrimers (Scheme 1). The physicochemical properties of the synthesized DENPs were determined using ultraviolet-visible light (UV-Vis) spectrometry, proton nuclear magnetic resonance ( $\left.{ }^{1} \mathrm{H} \mathrm{NMR}\right)$ spectroscopy, X-ray attenuation measurements, and transmission electron microscopy (TEM). Additionally, we employed molecular and cellular biology techniques, including cell viability assay, hemolytic assay, flow cytometry, and hematoxylin and eosin (HE) staining to evaluate the cytotoxicity and hemocompatibility of the nanoparticles. Furthermore, silver staining and TEM were conducted to verify the cellular uptake of the particles. Moreover, HeLa cells and the HeLa cell line xenograft tumor model were used to assess the specificity and sensitivity of the targeted CT imaging nanoparticles. Together, here, we, for the first time, developed FA-modified Au DENPs for in vitro and in vivo CT imaging of cervical cancer cells using dendrimer nanotechnology and PEGylation conjugation chemistry.

\section{Materials and Methods}

\subsection{Materials}

Ethylenediamine core amine-terminated PAMAM dendrimers of generation 5 (G5.NH2) with a polydispersity index less than 1.08 were purchased from Dendritech (Midland, MI). FA, FI, DTA, acetic acid, penicillin, streptomycin, and fetal bovine serum (FBS), and all other chemicals used in this study were obtained from Sigma-Aldrich (St. Louis, MO). Trypsin-ethylenediaminetetraacetate (EDTA), Dulbecco's phosphate-buffered saline (PBS), Dulbecco's modified Eagle medium (DMEM), and bovine serum albumin (BSA) were obtained from GIBCO-BRL. Regenerated cellulose dialysis membranes were purchased from Fisher Scientific (Hampton, NH). The FI, FA, and DTA functionalized G5 were synthesized as described previously (26). We used FI- and DTA-functionalized G5 without FA conjugation as a negative control. The average numbers of FI and FA moieties that were conjugated onto each G5 dendrimer are approximately 4.5 and 4.1 , respectively. 


\subsection{Synthesis of FI-, FA-, and DTA-functiona- lized Au DENPs}

$\mathrm{Au}$ DENPs-FI-FA-DTA complexes were prepared by adding $\mathrm{HAuCl}_{4}$ to a methanol/water mixture solution containing G5 at a molar ratio of G5 atoms equivalent to 1:50. The product was further modified by FI, FA, and DTA and then by acetylation of the remaining terminal amines of the dendrimers, as described previously $(10,17,23,27-28)$.

\subsection{Characterization of the physicochemical properties of the synthesized DENPs}

The UV-Vis spectrum of the Au DENPs was measured using a Perkin-Elmer Lambda 20 UV-Vis spectrometer. The ${ }^{1} \mathrm{H}$ NMR spectrum were determined on a Bruker DRX 400 NMR spectrometer. Samples were dissolved in $\mathrm{D}_{2} \mathrm{O}$ before the NMR measurements. TEM measurements were conducted at a voltage of $200 \mathrm{kV}$ using a JEOL 2010F analytical electron microscope equipped with an energy dispersive spectroscopy (EDS) system. $5 \mu \mathrm{L}$ of $\mathrm{Au}$ DENPs solution $(3 \mathrm{mg} / \mathrm{mL})$ was applied onto a carbon-coated copper grid and the samples were air dried before the experiments.

\subsection{Cell cultures and biological evaluation}

HeLa cells and SKOV-3 cells were purchased from Shanghai Cell Bank and continuously grown in two 10-cm culture dishes, one in FA-free medium and the other in regular DMEM cell culture medium containing $2.5 \mu \mathrm{M}$ FA, supplemented with penicillin, streptomycin, $10 \%$ heat-inactivated FBS. The cells grown in FA-free medium express high-levels of FAR (HFAR). By contrast, the cells grown in FA-containing medium display low FAR expression (LFAR).

\subsection{Assessment of cytotoxicity of acetylated Au DENPs}

Cell viability was measured using the 3-[4,5-dimethylthiazol-2-yl]-2,5-diphenyltetrazolium bromide (MTT) method. Briefly, HeLa cells were plated into a 96-well plate at a density of $5 \times 10^{3}$ cells/well. After overnight culture, functionalized $\mathrm{Au}$ DENPs was added to the cells at varying concentrations ranging from $0 \mu \mathrm{M}$ to $2 \mu \mathrm{M}$. $24 \mathrm{~h}$ after the incubation with $\mathrm{Au}$ DENPs, the medium in each well was replaced with a serum-free medium containing MTT solution. Following incubation with the MTT solution for $4 \mathrm{~h}$ at $37^{\circ} \mathrm{C}$, the cells were washed with PBS buffer and dimethyl sulfoxide was added to dissolve the MTT formazan crystals that were taken up by viable cells. The absorbance values of each well were determined using a microplate reader at a wavelength of $490 \mathrm{~nm}$.

Meanwhile, HE staining was performed to evaluate the cell morphology after the cells were exposed to acetylated Au DENPs. HeLa cells were plated onto a poly-L-lysine-coated coverslip at a density of $3 \times 10^{5}$ cells/well in 6-well cell culture plates. The cells were grown for $24 \mathrm{~h}$ to $\sim 80 \%$ confluence and incubated with acetylated Au DENPs for $4 \mathrm{~h}$. The cells were then washed three times with PBS and fixed with a $0.1 \mathrm{M}$ phosphate buffer containing $4 \%$ paraformaldehyde for $2 \mathrm{~h}$. After two washes with PBS for 5min, the cells were incubated in a solution containing hematoxylin for $30 \mathrm{~s}$ in a Coplin jar, rinsed with water for $1 \mathrm{~min}$, and then stained with $1 \%$ eosin Y solution for $30 \mathrm{~s}$. After the HE staining, the cells were dehydrated and the cover slips were mounted onto glass slides. The morphology of the cells was examined using an optical microscope.

\subsection{Flow cytometry analysis}

HeLa cells were plated at a density of $5 \times 10^{5}$ cells per well in 12-well plates in four replicates and grown to $\sim 80 \%$ confluence after overnight culture at $37^{\circ} \mathrm{C}$ and $5 \% \mathrm{CO}_{2}$. The cells were then incubated with fresh medium containing varying concentrations of $\mathrm{Au}$ DENPs-FA at $37^{\circ} \mathrm{C}$ and $5 \% \mathrm{CO}_{2}$ for $24 \mathrm{~h}$. The cells $\left(1 \times 10^{5}\right.$ cells $)$ were harvested by trypsinization, resuspended in PBS containing 0.1\% bovine serum albumin, and subsequently analyzed using a Becton Dickinson FACScan flow cytometer to measure the FL1 fluorescence intensity.

\subsection{Determination of cellular uptake of acetylated Au DENPs}

The cellular uptake of acetylated Au DENPs was determined by inductively coupled plasma atomic emission spectroscopy (ICP-AES), TEM, and silver staining. HeLa-HFAR cells were plated at a density of $5 \times 10^{5}$ cells/well in a 12-well plate. 24 hours later, the cells were exposed to $50 \mathrm{nM}$ or $200 \mathrm{nM}$ functionalized $\mathrm{Au}$ in FA-free medium or FA-DMEM at $37^{\circ} \mathrm{C}$ for $24 \mathrm{~h}$. After the incubation, the cells were then extensively washed once with Versene, twice with PBS, and three times with Hank's buffered salt solution (HBSS). Following the extensive washes, the cells were then harvested by trypsinization, resuspended in $200 \mu \mathrm{L}$ of PBS, and further diluted with $1.8 \mathrm{~mL}$ of $10 \%$ FBS in PBS. After the total cell number was determined by cell counting, the cells were centrifuged and lysed in an aqua regia solution to digest the Au DENPs. The cellular $\mathrm{Au}$ uptake was then determined using a Finnigan instrument.

To perform silver staining, Hela cells were plated at a density of $1.25 \times 10^{5}$ cells / well into 3 wells of a 24-well plate 24 hours prior to the experiments. One hour before the experiment, the cells were rinsed four times with DMEM and then incubated with 
$50 \mathrm{nM}$ functionalized $\mathrm{Au}$ DSNPs. $24 \mathrm{~h}$ after the incubation," the HeLa-HFAR and HeLa-LFAR cells were harvested by tripsinization and spun onto slides using a Shandon Cytospin 3 cytocentrifuge. The slides were then treated with Lugol's solution and subjected to silver staining with a silver enhancement kit according to the manufacturer's protocols. The silver staining time was optimized to achieve the best staining results and we obtained the best contrast between the control cells and the cells treated with $\mathrm{Au}$ DSNPs when a 5-minute silver staining procedure was performed. Meanwhile, we also employed a microscope to verify the cell morphology after the silver staining.

To examine the distribution of the acetylated $\mathrm{Au}$ DENPs within the cells using TEM, HeLa cells were plated at a density of $3 \times 10^{5}$ cells per well in 6-well plates. 24 hours later, the cells were incubated with 2 $\mu \mathrm{M}$ acetylated $\mathrm{Au}$ DENPs for 12 hours at $37^{\circ} \mathrm{C}$. The cells were then harvested and sequentially fixed with $2.5 \%$ glutaraldehyde in a $0.2 \mathrm{M}$ phosphate buffer for $12 \mathrm{~h}$ at $4{ }^{\circ} \mathrm{C}$ and with $1 \% \mathrm{OSO}_{4}$ in a $0.2 \mathrm{M}$ phosphate buffer for $2 \mathrm{~h}$ at $4{ }^{\circ} \mathrm{C}$. After three washes with PBS, the cells were subjected to ethanol series dehydration with $30 \%, 50 \%, 70 \%, 95 \%$, and $100 \%$ ethanol solutions and embedded with Epon 812. The embedded cells were subsequently sectioned using a Reichart ultramicrotome. The sections with a thickness of $75 \mathrm{~nm}$ were mounted onto 200-mesh copper grids and then subjected to counterstaining with uranyl acetate and lead citrate for 5 min prior to TEM measurements. The visualization of the cells on the grids was performed using an $\mathrm{H} 600$ transmission electron microscope at a voltage of $60 \mathrm{kV}$.

To examine the cells with a confocal microscope, the cells were plated onto a plastic coverslip and incubated with functionalized Au DSNPs for $24 \mathrm{~h}$. After 3 washes with PBS, the nuclei were counterstained with DAPI for 10 seconds. The FI fluorescence was examined on an Olympus FluoView 500 laser scanning confocal microscope with an excitation wavelength of $488 \mathrm{~nm}$ and emission wavelengths of 505-525. All samples were scanned using a 60x water-immersion objective lens and further magnified with the FluoView software. The same method was also applied to analyze the xenograft tumor tissues.

\subsection{In vitro micro-CT imaging}

$\mathrm{HeLa}$ cells were incubated with $\mathrm{Au}$ DENPs-FI-FA-DTA and Au DENPs-FI -DTA at concentrations of 0,100 , or $300 \mathrm{nM}$ for $24 \mathrm{~h}$ at $37^{\circ} \mathrm{C}$. After three washes with PBS, approximately $1.5 \times 10^{6}$ cells were harvested by trypsinization and resuspended in $100 \mu \mathrm{L}$ of PBS in a $0.5 \mathrm{~mL}$ Eppendorf tube. The cell suspension placed in a self-designed scanning holder was scanned using a micro-CT imaging system. The CT images were then processed on a micro-CT imaging workstation.

\subsection{In vivo micro-CT imaging}

All animal experiment protocols were approved by the Institutional Committee for Animal Care and carried out according to the policy of the National Ministry of Health. $1 \times 10^{6} \mathrm{HeLa}$ cells were subcutaneously injected on the right side of the backs of 4-to 6-week-old male BALB/c nude mice. Approximately 3 weeks after the injection, the tumor nodules reached a volume of $1.0 \pm 0.15 \mathrm{~cm}^{3}$ and the tumor was examined by gross inspection and $\mathrm{HE}$ staining to confirm the features of HeLa cells. The mice were then placed in a scanning holder and scanned by a micro-CT imaging system using similar parameters as described above for the in vitro studies. CT scanning was performed at $0,2,4,6$ and 12 hours after the intratumoral or intraperitoneal injection of $\mathrm{Au}$ DENPs (29). The CT image data analysis was carried out on a micro-CT imaging workstation.

\subsection{In vivo biodistribution of $\mathrm{Au}$}

$0,3,6,9$, and 12 hours after injection of the DENPs via the intraperitoneal and intravenous routes, the mice were subjected to the micro-CT imaging as described above and subsequently euthanized by $\mathrm{CO}_{2}$ inhalation. After the sacrifice, the organs of the mice, including the tumor, heart, lung, stomach, spleen, liver, intestines, kidney, testicle, blood, tumor, and brain were harvested and weighed. The organs were processed into $1-2 \mathrm{~mm}^{2}$ pieces and incubated in the aqua regia solution for 4 hours. The $\mathrm{Au}$ content in the organs was measured by using ICP-AES. After the micro-CT imaging, mice were anesthetized by intraperitoneal injection of chloral hydrate and subjected to endovascular perfusion with $4 \%$ paraformaldehyde via an open-chest, left cardiac ventricle puncture approach. The organs of the mice, including the heart, lung, spleen, liver, intestines, and kidney were subjected to rapid frozen sectioning, cut into sections $(8 \mu \mathrm{m})$ with a cryostat, and collected on poly-D-lysine-coated slides for HE staining and silver staining.

\subsection{Statistical analysis}

Student's t-test was performed to compare the difference between two groups, while one-way analysis of variance (ANOVA) followed by LSD's tests was employed to evaluate the difference between multiple groups. All data were presented as means \pm S.D. All statistical analyses were conducted using SPSS 15.0 software (SPSS Inc., Chicago, IL). The 
$p$ values $<0.05$ were considered statistically significant.

\section{Results and discussion}

\subsection{Synthesis and characterization of $A u$ DENPs-FI-FA-DTA nanoparticles}

Our previous studies have demonstrated the synthesis and characterization of acetamidefunctionalized $\mathrm{Au}$ DENPs and dye-functionalized $\mathrm{Au}$ DENPs with acetamide surface groups (30-33). Similarly, we found that FI-, FA-, and DTAfunctionalized $\mathrm{Au}$ with close-to-neutral surface charges could be spontaneously formed by acetylation of the remaining terminal amines of the dendrimers (figure $1 \mathrm{a}$ ). As shown in Fig. $1 \mathrm{~b}$ and 1c, the UV-Vis spectrum of both Au DENPs-FI-DTA and Au DENPs-FI-FA-DTA display absorbance peaks at $510 \mathrm{~nm}$, corresponding to the characteristic absorption peaks of FI and AuNPs, which can be well explained by the overlapping between the surface plasmon resonance peak $(510 \mathrm{~nm})$ of AuNPs and the absorption of FI moieties. By contrast, Au DENPs exhibits only the characteristic FA absorbance peak at $280 \mathrm{~nm}$. The ${ }^{1} \mathrm{H}$ NMR spectrum of the Au DENPs are shown in Fig. 1d and 1e. The peaks located at 2.30-3.40 ppm and $1.95 \mathrm{ppm}$ match the characteristic absorption peaks of the -NH protons of G5 and $-\mathrm{COCH}_{3}$ protons of DTA. The absorption peaks of $-\mathrm{COCH}_{3}$ protons located at $1.87 \mathrm{ppm}$ in both $\mathrm{Au}$ DENPs-FI-DTA and Au DENPs-FI-FA-DTA confirms further acetylation of the remaining amines of the dendrimers. The absorption peaks of the protons of FI and FA molecules were observed between $6.00-8.00 \mathrm{ppm}$. A slight difference could be found in Fig. 1e at approximately $7.5 \mathrm{ppm}$, which corresponds to the UV-Vis spectrum of the FA group of $\mathrm{Au}$ DENPs-FI-FA-DTA.

Next, TEM was performed to determine the physiochemical properties of the formed Au DENPs. As shown in Fig. 1i and $\mathrm{g}$, Au DENPs range in size from 2 to $6 \mathrm{~nm}$ and no difference in the morphologies between $\mathrm{Au}$ DENPs-FI-DTA and $\mathrm{Au}$ DENPs-FI-FA-DTA was observed. Additionally, the formed $\mathrm{Au}$ DENPs are water soluble and stable for at least 6 months in both PBS and cell culture medium.
No significant difference in DTA was found between the PBS buffer (Fig 1g) and cell culture (Fig.1h).

\subsection{Cytotoxicity of acetylated Au DENPs}

Next, we performed HE staining to evaluate the morphological changes of HeLa cells after the cells were exposed to the acetylated Au DENPs. As shown in Fig 2, our data showed that the cells appear as normal and healthy as the untreated control cells, even when the concentration of DENPs was increased to $2 \mu \mathrm{M}$. These findings suggest that acetylated $\mathrm{Au}$ does not cause remarkable cytotoxic effects on HeLa cells within certain concentrations.

Compared with the control group, no changes were observed in the morphologies of HeLa cell. FA by itself does not affect the cell viability, compared with the control in our experiment. In addition, MTT assay also shows that a 24-hour incubation with NPs does not induce cell death in HeLa cells (Fig 3). Even a ten-fold increase in the dose of FA does not significantly influence the cell viability of HeLa cells, probably because the NPs possess both an essentially inert, nontoxic $\mathrm{Au}$ core and biocompatible surface-confined FA (34-35).

Cell cycle arrest is one of the most important features of cytotoxicity resulting from drug treatments. Cell phase distributions after drug treatments are usually analyzed by determining cellular DNA contents, and the fraction of cell population in the sub-G1 phase is usually referred to cells that undergo apoptosis (37-38). To examine the effects of acetylated Au DENPs on induction of apoptosis, the treated cells were subjected to flow cytometric analysis (8). The sub-G1 fractions of HeLa cells that were exposed to acetylated Au DENPs at concentrations of $100 \mathrm{mM}$ and $300 \mathrm{mM}$ were $4.87 \% \pm 0.87 \%$ and $4.98 \% \pm 0.91 \%$, respectively (Fig 4 ). However, no statistically significant differences were observed between the treated and the untreated negative control cells. As shown in Table 1, acetylated $\mathrm{Au}$ DENPs also does not affect the cell cycle distribution of HeLa cells, compared with the untreated negative control. These results further confirm that acetylated Au DENPs do not cause any cytotoxic effects, when they are used at varying concentrations as indicated.

Table 1. Flow cytometric analysis to determine apoptosis and cell cycle of HeLa cells 4 hours after exposed to the $\{($ Au0)50-G5.NHAc-FA5 $\}$ DENPs (mean \pm S.D., $n=4)$.

\begin{tabular}{|c|c|c|c|c|c|}
\hline \multirow[t]{2}{*}{ Group } & \multirow[t]{2}{*}{ Apoptosis (\%) } & \multicolumn{4}{|c|}{ Cell cycle (\%) } \\
\hline & & G0-G1 & G2-M & $\mathrm{S}$ & G2/G1 \\
\hline Control & $5.17 \pm 0.93$ & $59.45 \pm 6.67$ & $25.17 \pm 5.37$ & $5.26 \pm 1.76$ & $1.79 \pm 0.01$ \\
\hline $100 \mathrm{mM}(\mathrm{Au})$ & $4.87 \pm 0.87$ & $65.42 \pm 6.21$ & $30.22 \pm 5.27$ & $4.36 \pm 1.98$ & $1.81 \pm 0.01$ \\
\hline $300 \mathrm{mM}(\mathrm{Au})$ & $4.98 \pm 0.91$ & $66.68 \pm 6.93$ & $29.96 \pm 6.54$ & $3.35 \pm 1.83$ & $1.85 \pm 0.01$ \\
\hline
\end{tabular}




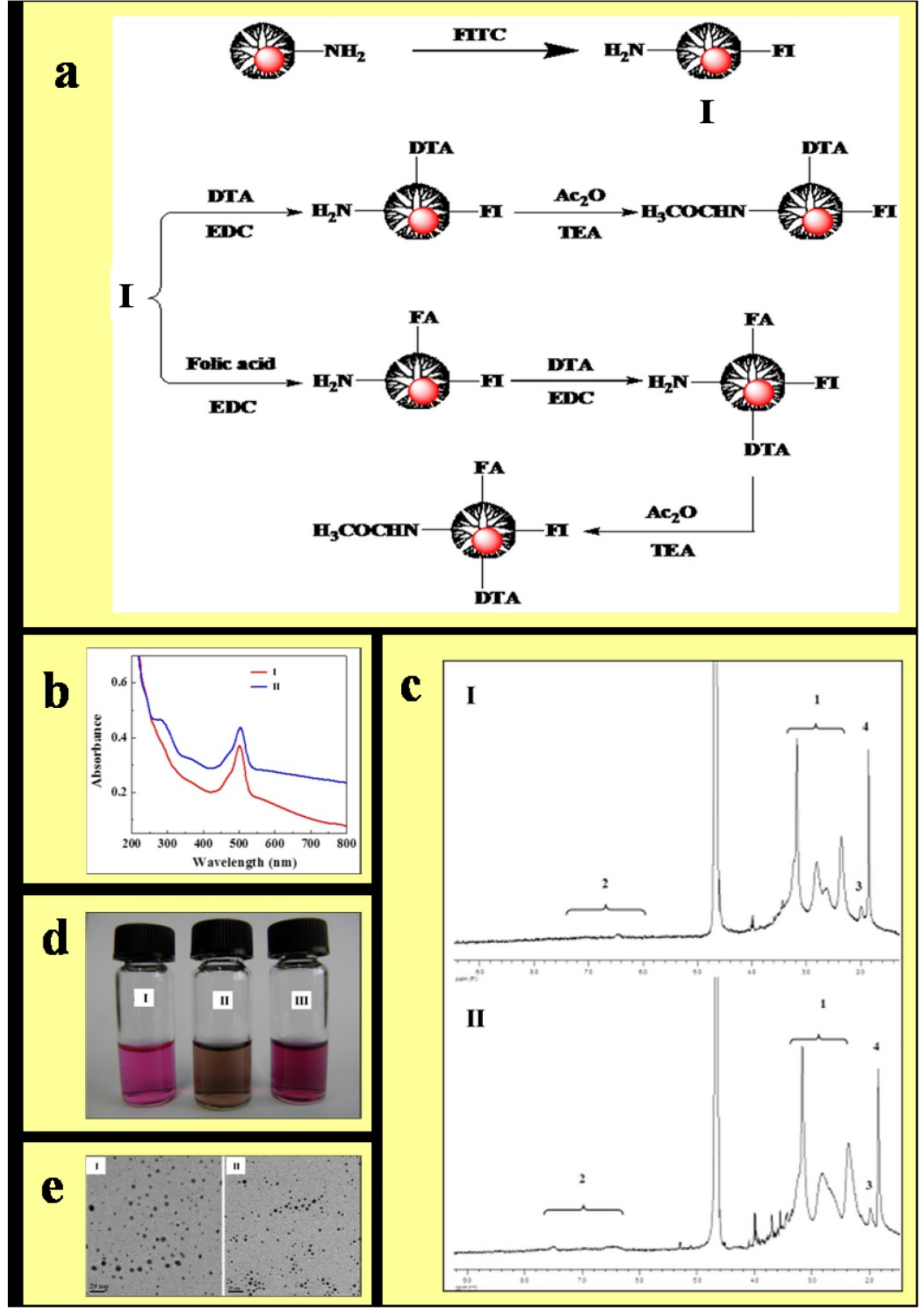

Figure 1. Synthesis and characterization of the $A u$ DENPs-FI-DTA and Au DENPs-FI-FA-DTA. (1) Schematic illustration of the preparation of $\mathrm{Au}$ DENPs-FI-DTA and Au DENPs-FI-FA-DTA(a). Au DENPs-FI-FA-DTA was synthesized by adding $\mathrm{HAuCl}_{4}$ to a methanol/water mixture solution containing $\mathrm{G} 5$ at a molar ratio of $\mathrm{G} 5$ atoms equivalent to 1:50. The product was further conjugated with $\mathrm{FI}, \mathrm{FA}$, and DTA and then acetylated by the remaining terminal amines of the dendrimers (2) UV-vis spectrum of the formed $\mathrm{Au}$ DENPs-FI-DTA(b,l) and Au DENPs-FI-FA-DTA (b,II) were collected using a Perkin-Elmer Lambda 20 UV-vis spectrometer. The UV-Vis spectrum of both Au DENPs-FI-DTA and Au DENPs-FI-FA-DTA exhibits absorbance peaks at $510 \mathrm{~nm}$. (3) IH NMR spectrum of $\mathrm{Au}$ DENPs-FI-DTA (c,l) and $\mathrm{Au}$ DENPs-FI-FA-DTA (c,Il) were determined on a Bruker DRX 400 NMR spectrometer, after the samples were dissolved in $\mathrm{D}_{2} \mathrm{O}$. The absorption peaks of $-\mathrm{COCH}_{3}$ protons located at $1.87 \mathrm{ppm}$ in both Au DENPs-FI-DTA and Au DENPs-FI-FA-DTA indicates further acetylation of the remaining amines of the dendrimers. (4) Photographs of cell culture medium (d, I), Au DENPs-FI-FA-DTA dispersed in PBS buffer (d,II), and cell culture medium (d, III) were taken with a digital camera. The micrograph show that Au DENPs particles range in size from 2 to $6 \mathrm{~nm}$ and there is no difference in the morphologies between Au DENPs-FI-DTA and Au DENPs-FI-FA-DTA. (5) $5 \mu \mathrm{L}$ of Au DENPs solution $(3 \mathrm{mg} / \mathrm{mL})$ was applied onto a carbon-coated copper grid. After the samples were air dried, TEM imaging of the nanoparticles Au DENPs-FI-DTA (e,l) and Au DENPs-FI-FA-DTA (e,II) were then performed using a JEOL 2010F analytical electron microscope equipped with an energy dispersive spectroscopy (EDS) system.
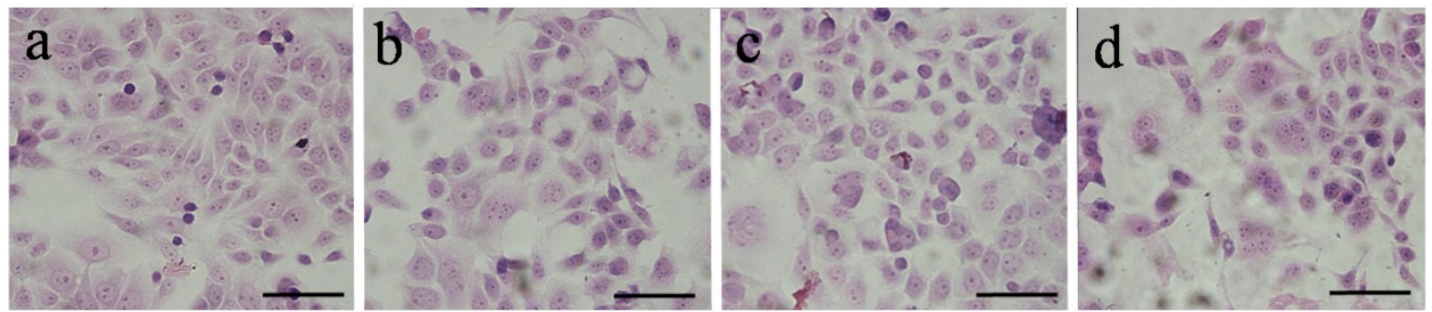

Figure 2. Representative micrograph of HE-stained HeLa cells. HeLa cells were incubated with acetylated Au DENPs for $4 \mathrm{~h}$ and fixed with a $0.1 \mathrm{M}$ phosphate buffer containing $4 \%$ paraformaldehyde for $2 \mathrm{~h}$ after three washes with PBS. HE staining was then performed as described in the Materials and Methods and the morphology of the cells was examined using an optical microscope. (a) negative control cells without treatment and cells treated with [(Au0)300-G5.NHAc-(PEGFA)-mPEG] DENPs at a Au concentration of (b) $100 \mathrm{mM}$, (c) $300 \mathrm{mM}$ and (d) $2 \mu \mathrm{M}$ for $24 \mathrm{~h}$. Scale bar measures $50 \mu \mathrm{m}$. The HE-stained results showed that, after the DENPs treatment, the cells appear as normal and healthy as the untreated control cells, suggesting that acetylated Au does not induce cytotoxic effects on HeLa cells. $(\times 200$ magnification) $(300 \times 300 \mathrm{DPI})$. 


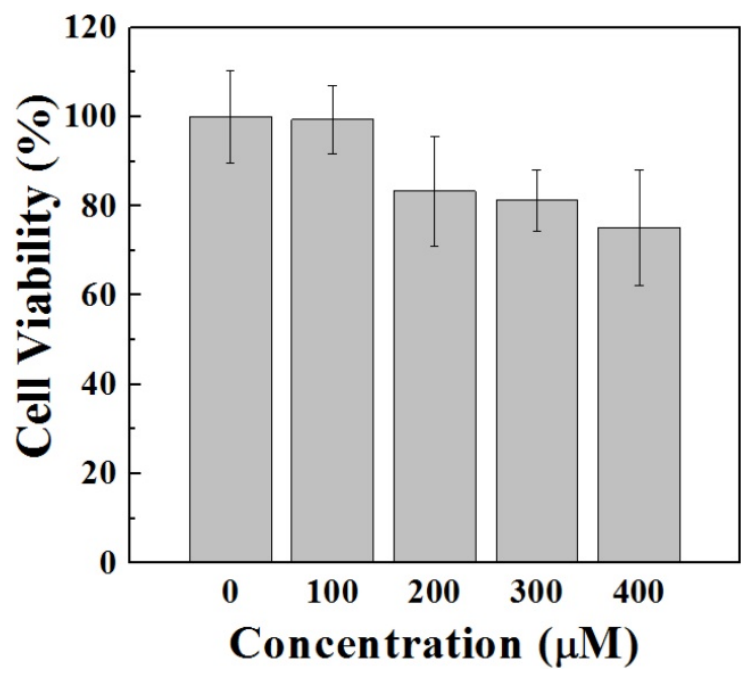

Figure 3. Assessment of the viability of HeLa cells following the incubation with [(Au0)300-G5.NHAc-(PEG-FA)-mPEG] DENPs. HeLa cells were incubated with functionalized Au DENPs at varying concentrations ranging from $0 \mu \mathrm{M}$ to $400 \mu \mathrm{M}$. $24 \mathrm{~h}$ after the incubation with Au DENPs, MTT assay was conducted as described in the Materials and Methods to evaluate the cell viability. The absorbance values of each well were determined using a microplate reader at a wavelength of $490 \mathrm{~nm}$. The MTT assay results show that functionalized Au DENPs does not induce cell death in HeLa cells.

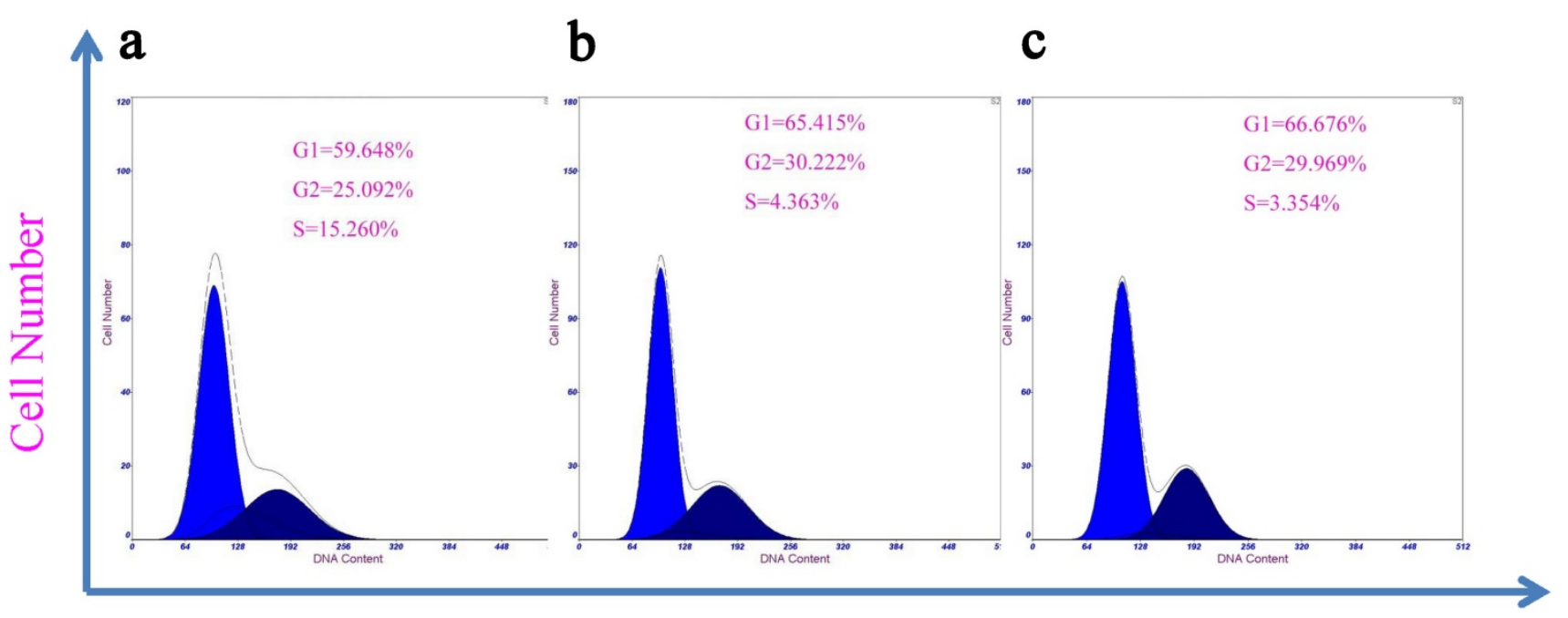

\section{DNA Content}

Figure 4. Flow cytometry analysis of HeLa cells incubated in the absence (a) or presence of $\{(A u 0) 50-G 5 . N H A c-F A 5\}$ DENPs at $100 \mathrm{mM}$ (b) and $300 \mathrm{mM}$ (c), respectively, for 4 hours $(n=3)$. HeLa cells were incubated with fresh medium containing varying concentrations of Au DENPs-FA at $37^{\circ} \mathrm{C}$ and $5 \% \mathrm{CO} 2$ for $24 \mathrm{~h}$. The cells $\left(1 \times 10^{5}\right.$ cells) were then harvested by trypsinization, resuspended in PBS containing $0.1 \%$ bovine serum albumin, and subsequently analyzed using a Becton Dickinson FACScan flow cytometer to measure the FLI fluorescence intensity. The data demonstrate that acetylated Au DENPs does not induce apoptotic cell death in HeLa cells.

\subsection{In vitro cellular uptake of Au DENPs-FI-FA-DTA}

In presence of the targeting ligand FA, cervical cancer cells that express elevated levels of high-affinity FAR should be able to take up the synthesized DENPs. We then investigated the cellular uptake of the AuNPs by HeLa cells. After incubation with the DENPs for $4 \mathrm{~h}$, both HeLa-HFAR and HeLa-LFAR cells were subjected to silver staining and examined under an optical microscope. As shown in Fig 5, the cells incubated with Au DENPs-FI-FA-DTA at the concentrations of either $100 \mathrm{mM}$ (Fig.5b and e) or $300 \mathrm{mM}$ (Fig.5c and f) were positively silver-stained and the color become darker when $\mathrm{Au}$ was used at higher concentrations (Fig. $5 \mathrm{c}$ and f). These findings indicate that the linking of the FA moiety to the nanoparticles enables the specific uptake of Au DENPs-FI-FA-DTA by cervical cancer cells with high levels of FAR expression via a receptor-mediated mechanism (23). The non-specific uptake of the nanoparticles by HeLa cells may result from phagocytosis or passive diffusion through the cell plasma membrane (36-39).

Next, TEM was performed to confirm the subcellular distribution of $\mathrm{Au}$ in cancer cells. Our data showed that the electron-staining particles in cells 
treated with FA were significantly increased (Fig 6b) in the cytoplasm of the HeLa cells, compared to those without electron-staining particles in the absence of FA treatment (Fig 6a). The TEM results further demonstrated that the $\mathrm{Au}$ DENPs-FI-FA-DTA were taken up by the cells instead of adhering to the cell surface. Based on previous studies, the uptake of $\mathrm{Au}$ probably occurs through phagocytosis or passive diffusion via the cell plasma membranes (39). Taken together, our data showed that the linking of FA to Au particles remarkably facilitate the specific uptake of the nanoparticles by HeLa cells through receptor-mediated endocytosis (40). The specific uptake of FA underlies the mechanism by which the particles can serve as imaging probes for targeted CT imaging of HeLa cells in vitro.
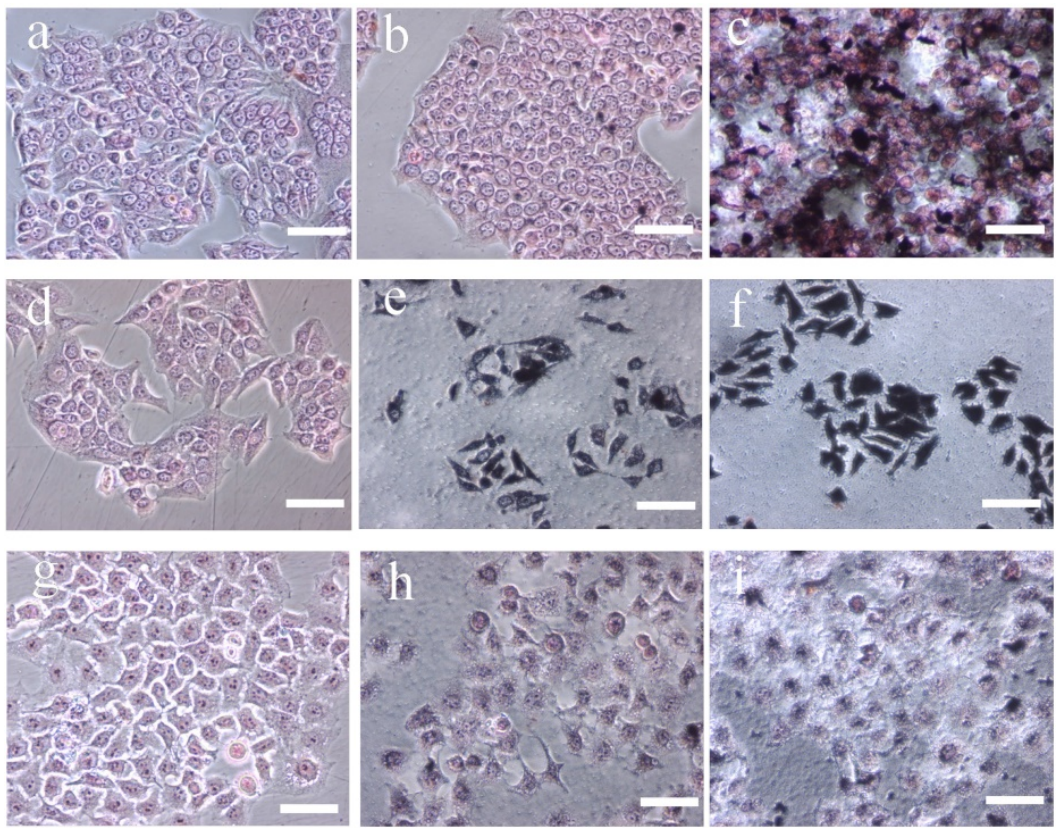

Figure 5. Silver staining of Hela cells treated with functionalized Au DSNPs. Hela cells were plated at a density of $1.25 \times 10^{5}$ cells/well into 3 wells of a $24-$ well plate and incubated with $50 \mathrm{nM}$ functionalized Au DSNPs. The HeLa-HFAR and HeLa-LFAR cells were harvested by tripsinization and silver staining was performed as described in the Materials and Methods. The cell morphology after the silver staining was examined with a microscope. Representative microscopic images are presented here. HeLa-HFAR (a-c), HeLa-LFAR $(\mathrm{d}-\mathrm{f}$ ) and non-FA expressing cells (ovarian cancer cell lines SKOV-3)(g-i) after silver staining. (a), (d) and (g) are negative control cells that received no treatment. The cells were incubated with Au DENPs-FI-FA-DTA at the Au concentration of $100 \mathrm{mM}$ (b, e and h) and $300 \mathrm{mM}$ (c, f and i), respectively. After the incubation, the cells become dark and are positively silver-stained, indicating that the linking of the FA moiety to the nanoparticles allows the specific uptake of Au DENPs-FI-FA-DTA by cervical cancer cells with high levels of FAR expression via a receptor-mediated mechanism. Scale bar measures $50 \mu \mathrm{m}(\times 200$ magnification $)(300 \times 300 \mathrm{DPI})$.

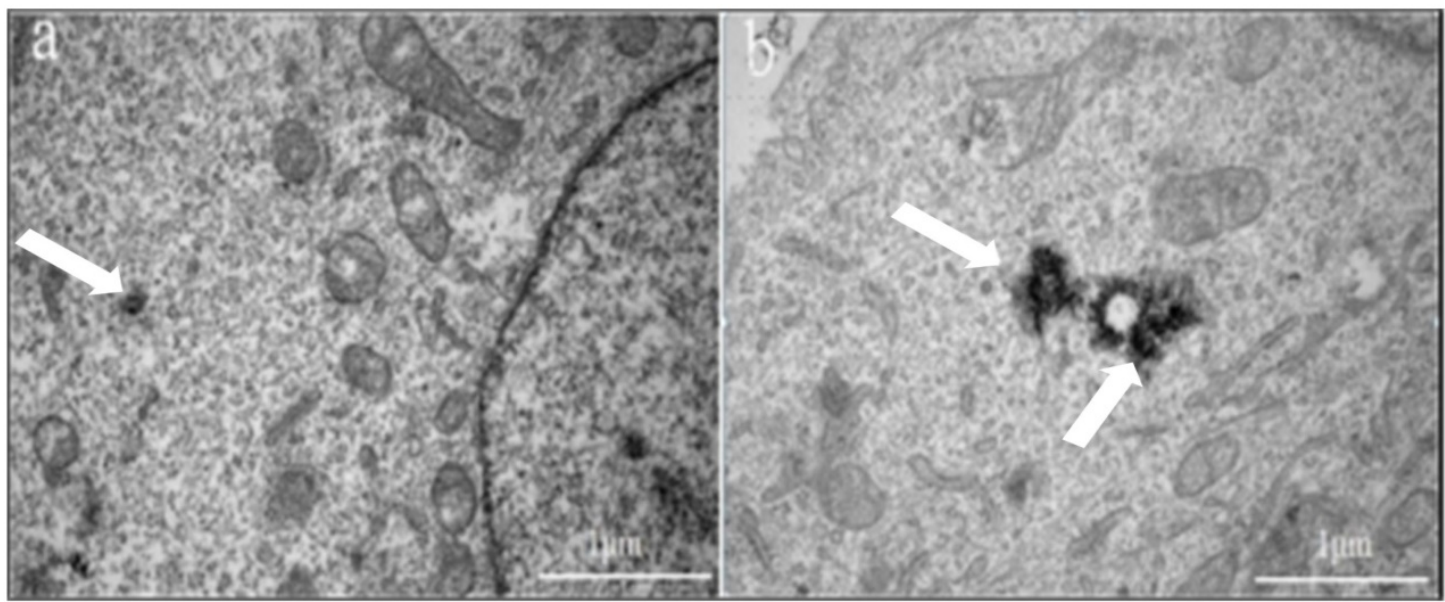

Figure 6. TEM images of HeLa cell following the cellular uptake of Au DENPs-FI-FA-DTA. Hela cells received no treatment (a), or were incubated with Au DENPs-FI-FA-DTA at $2000 \mathrm{nM}$ for 12 hours (b). The white arrows indicates the nanoparticles in the lysosomes of the cells. The TEM micrographs showed that the electron-staining particles in cells treated with FA are concentrated in the lysosomes in the cytoplasm of the HeLa cells, but are absent in the untreated cells, demonstrating that the Au DENPs-FI-FA-DTA were specifically taken up by the cells instead of adhering to the cell surface. Scale bar measures $50 \mu$ m. 
(a)

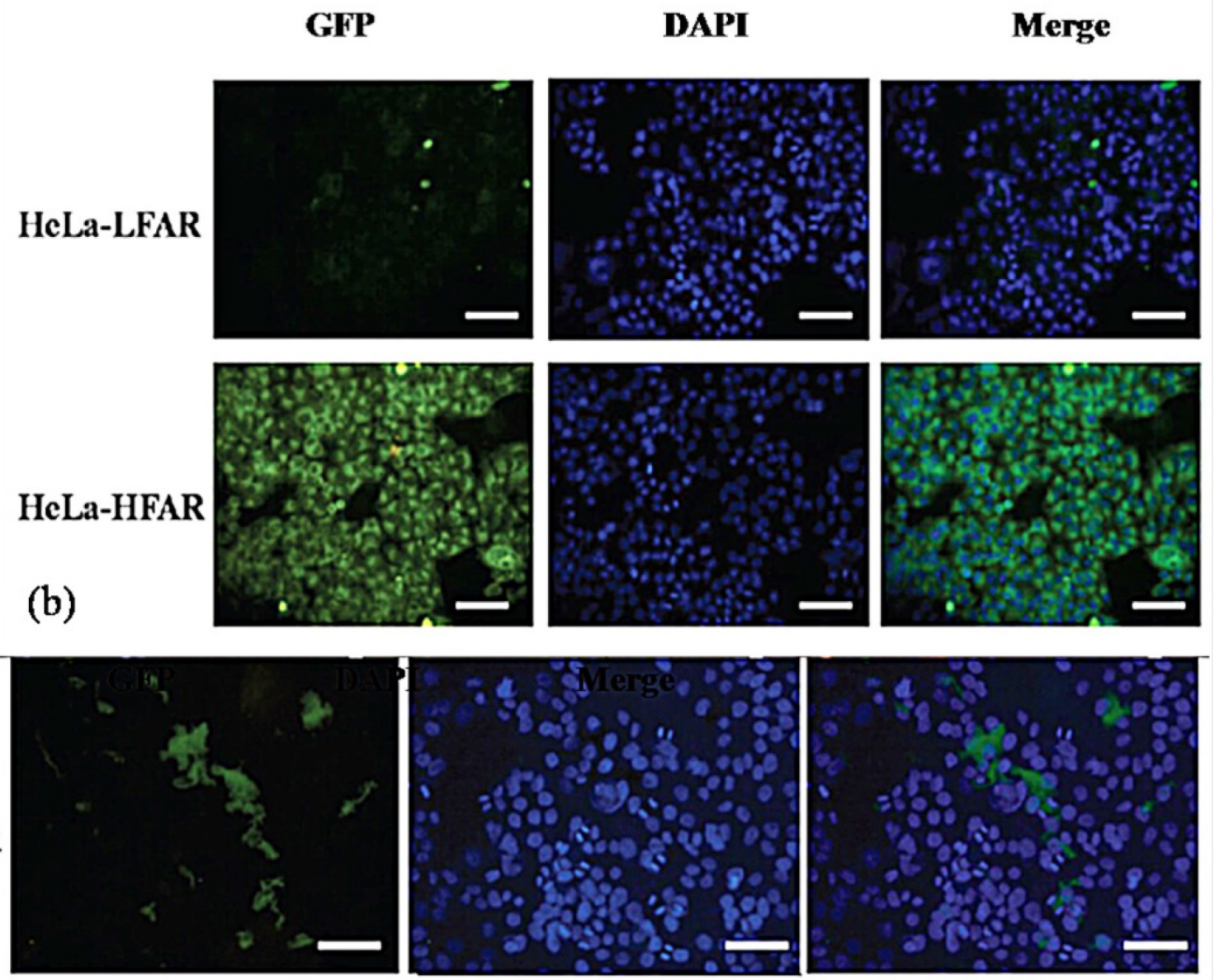

Figure 7. Confocal microscopy images of HeLa-LFAR cells and HeLa-HFAR cells with Au DENPs-FI-FA-DTA for 2 hours (a) and HeLa tumor xenografts (b). The cells were plated onto a plastic coverslip and incubated with functionalized Au DSNPs for $24 \mathrm{~h}$. After 3 washes with PBS, the nuclei were counterstained with DAPI for 10 seconds. The FI fluorescence was then examined on an Olympus FluoView 500 laser scanning confocal microscope with an excitation wavelength of $488 \mathrm{~nm}$ and emission wavelengths of 505-525. The green coloration results from the Fl dye that is conjugated to the dendrimers. Positive fluorescence signals can be observed in both HeLa cells and in the HeLa cell line xenograft tumor tissues that express high levels of FR following the treatment with Au DENPs-FI-FA-DTA, but no green signals were detected after the treatment with DENPs without FA modification, which confirms the specificity of Au DENPs-FI-FA-DTA as imaging probes for targeted CT imaging of HeLa cells

\subsection{Expression of FR on both HeLa cells and xenografts}

The coupling of the FI moiety to the Au DENPs particles enables us to examine the cellular uptake of the particles using a confocal microscope. Notably, only HeLa-HFAR cells that were exposed to $\mathrm{Au}$ DENPs-FI-FA-DTA display positive fluorescence signals, which may result from the specific uptake of DENPs through the plasma membrane and into the cytoplasm of the cells (Fig. 7). By contrast, HeLa cells treated with DENPs without FA modification did not exhibit any fluorescence signals (Fig 7a). Likewise, fluorescence signals could also be clearly detected in the HeLa cell line xenograft tumor tissues that express high levels of FR following the treatment with DSNPs (Fig. 7b). However, no fluorescence signals are observed in both HeLa cells and the HeLa cell line xenograft tumor tissues following the treatment with
$\mathrm{Au}$, further confirming the specificity of $\mathrm{Au}$ DENPs-FI-FA-DTA as imaging probes for targeted CT imaging of HeLa cells.

\subsection{Targeted micro-CT imaging of HeLa cells in vitro}

We have demonstrated the targeting specificity of $\mathrm{Au}$ DENPs-FI-FA-DTA to FAR-overexpressing cancer cells and the unique $X$-ray attenuation property of the particles as described above. We next investigated the feasibility of using the particles as imaging probes for targeted CT imaging of HeLa cells in vitro. After incubation with Au DENPs-FI-DTA and Au DENPs-FI-FA-DTA for 4 hours, HeLa-HFAR cells were examined by micro-CT imaging. Given the difficulties associated with determining the brightness of the CT images of the cells that were exposed to varying concentrations of Au with the naked eyes, the 
signal intensity on the $\mathrm{CT}$ images must be quantitatively evaluated using the software supplied by the manufacturer. Our data showed that HeLa-HFAR cells exposed to either $\mathrm{Au}$ DENPs-FI-DTA or Au DENPs-FI-FA-DTA display higher CT signal intensities than control cells without the treatments (Fig. 8). Moreover, the HeLa-HFAR cells treated with DENPs also exhibit significantly higher X-ray attenuation than those cells that were exposed to $\mathrm{Au}$ DENPs-FI-DTA at the same $\mathrm{Au}$ concentrations. These results further highlight the roles of the FA moieties in mediating the specific targeting of FAR-overexpressing cancer cells, which underlies the mechanisms by which $\mathrm{Au}$ DENPs-FI-FA-DTA acts as imaging probes for targeted CT imaging of HeLa cells.

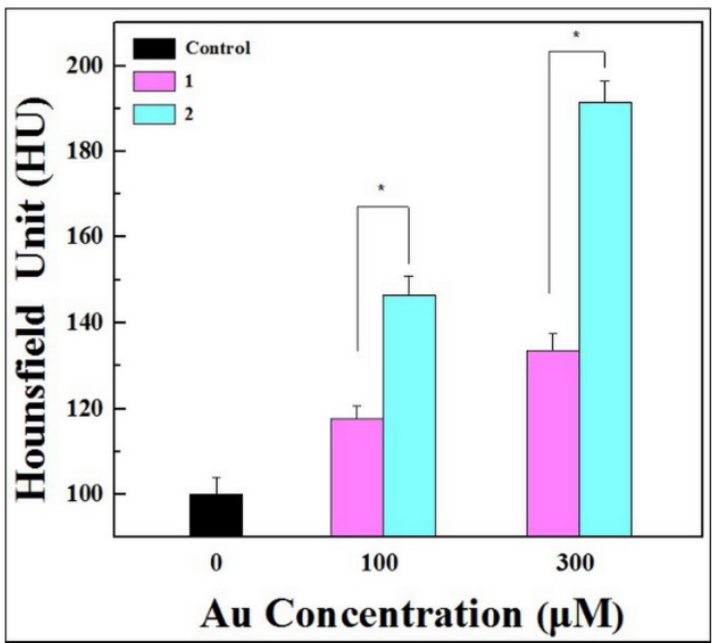

Figure 8. Representative transverse micro-CT images (a) and the $C T$ signal intensities (b) of the HeLa-HFAR cells exposed to [(Au0)300-G5.NHAc-mPEG] (1) and [(Au0)300-G5.NHAc-(PEG-FA)-mPEG] DENPs (2) at varying Au concentrations for 4 hours $(n=3)$. Scale bar measures $50 \mu \mathrm{m}$. HeLa cells were incubated with $\mathrm{Au}$ DENPs-FI-FA-DTA and Au DENPs-FI -DTA at concentrations of 0,100 , or $300 \mathrm{nM}$ for $24 \mathrm{~h}$ at $37^{\circ} \mathrm{C}$. After three washes with PBS, the cells were harvested by trypsinization and resuspended in PBS. The cell suspension placed in a self-designed scanning holder was scanned using a micro-CT imaging system. The CT images were then processed on a micro-CT imaging workstation. Our results showed that, after exposed to either $\mathrm{Au}$ DENPs-FI-DTA or Au DENPs-FI-FA-DTA, HeLa-HFAR cells display higher CT signal intensities than control cells without the treatments, which demonstrates the roles of the FA moieties in mediating the specific targeting of FAR-overexpressing cancer cells.

\subsection{Targeted micro-CT imaging of HeLa cells in vivo}

The remarkable effectiveness of the synthesized FA-coupled $\mathrm{Au}$ nanoparticles for the targeted CT imaging of HeLa cells in vitro prompted us to investigate their potential application in CT imaging of cervical cancer in vivo. To this end, a HeLa cervical cancer xenografts model in BALB/c nude mice was established by inoculating cells subcutaneously (Fig $9 \mathrm{a}$ and Fig 9b). Following intravenous injection, the
CT signal intensities from the HeLa cell xenografts treated with $\mathrm{Au}$ DENPs-FI-FA-DTA were much higher than those treated with the non-targeted DENPs at the same time points. Moreover, the HeLa cell xenografts pre-treated with free FA display much less CT intensity signals after injection of the targeted $\mathrm{Au}$ DENPs than those without the pretreatment with free FA (Fig 9b). These data showed that pre-treatment with free FA blocks the binding of $\mathrm{Au}$ to HeLa cells and then eliminates the enhancement in the CT signal intensities from the HeLa cell xenografts, which is mediated by the FA specific targeting. Hence, at the same time points, the CT signal intensities from the HeLa cell xenografts for Groups 3 and 5 did not show significant differences.

Similarly, following intraperitoneal injection of the nanoparticles, the CT signal intensities in Group 2 were much higher than those in Groups 4 and 6 at the same time points. However, pretreatment with free FA does not result in notable differences in the CT signal intensities. Importantly, we found that intravenous injection of $\mathrm{Au}$ DENPs-FI-FA-DTA results in a greater increase in $\mathrm{CT}$ signal intensity in the HeLa cell xenografts than intraperitoneal injection of the same particles at the same time points. However, when $\mathrm{Au}$ DENPs-FI-DTA or $\mathrm{Au}$ DENPs-FI-FA-DTA used in the HeLa cell xenografts pre-treated with free $\mathrm{FA}$, the injection route did not noticeably affect the CT image signal intensities at the same time points. Thus, our findings indicate that optimal CT imaging conditions are listed as below: (1) intravenous injection of the particles; (2) use of targeted particles Au DENPs; (3) CT scanning 6 hours after the intravenous injection of the particles. These data demonstrate that the synthesized DENPs hold great promise as nanoparticles for targeted CT imaging of human cancers with high levels of FAR expression.

Next, we performed ICP-AES to determine the biodistribution of the DENPs and the $\mathrm{Au}$ concentrations 6 hours following the injections through the two administration routes in the HeLa cell xenografts as well as in several major organs, including the blood, heart, lung, stomach, liver, spleen, intestine, brain, kidney, and testicle. Notably, following the intraperitoneal or intravenous injections of the targeted particles $\mathrm{Au}$ DENPs, the spleen displays the highest levels of Au uptake at the two time points as indicated. Less uptake of the $\mathrm{Au}$ particles is observed in other major organs, indicating that RES in those organs fails to attract the $\mathrm{Au}$ particles so that they can be effectively transported to the tumor tissues via the passive enhanced EPR effects (10). Aside from the passive EPR effects, FA-mediated active targeting of Au DENPs-FI-FA-DTA following 
intraperitoneal or intravenous injections leads to a much higher accumulation of $\mathrm{Au}$ in the HeLa cell xenografts via both injection routes than that in the non-targeted and free FA-blocked groups. This phenomenon serves to interpret the mechanism by which specific targeted CT imaging of the tumors works. The preferential accumulation of the Au-containing particles in the tumor tissues are consistent with the effectiveness of the nanoparticles in the targeted CT imaging of HeLa cells as described above. It will be very important to investigate the pharmacokinetic of the Au DENPs over extended time periods in order to fully understand the biodistribution of the NPs particles in the future.
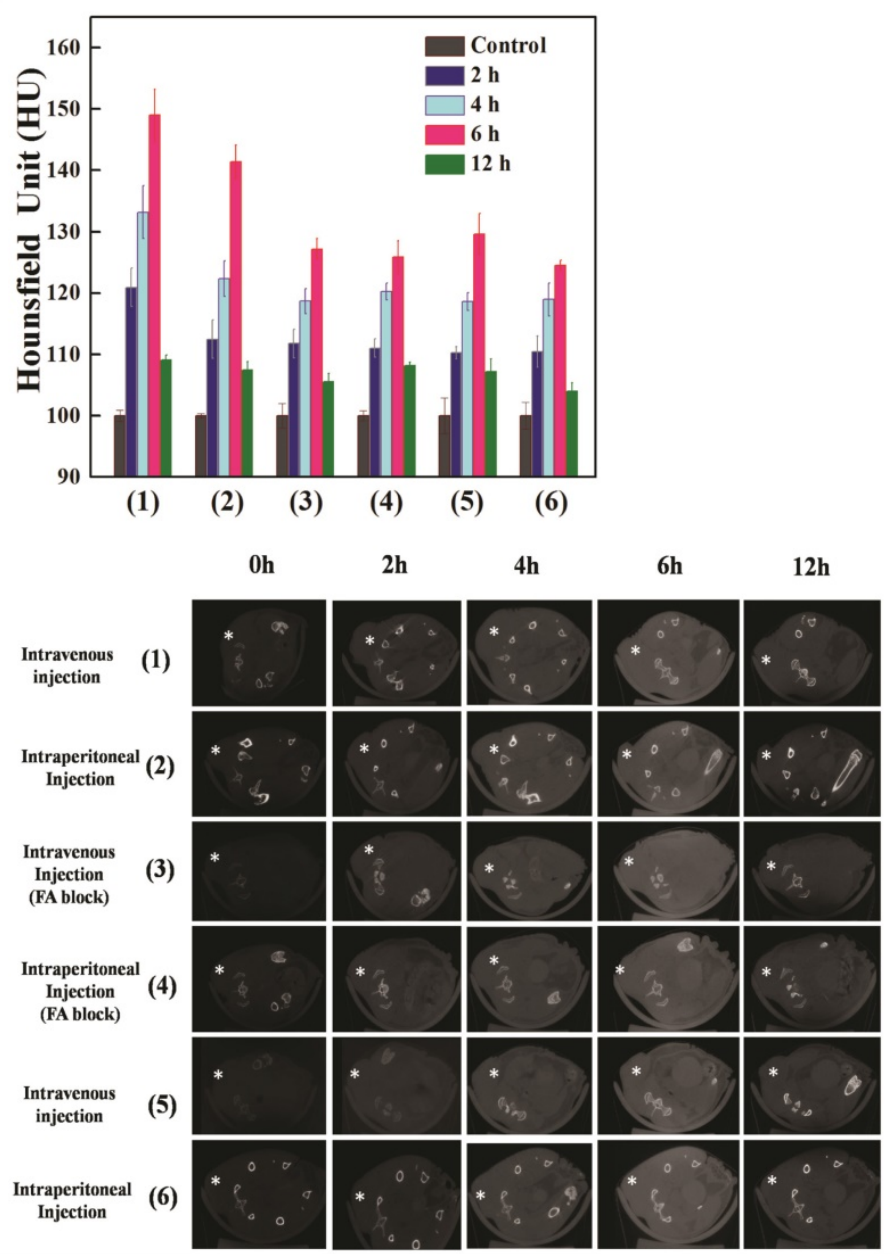

Figure 9. Representative transectional micro-CT images (a) and CT signal intensities (b) of the HeLa cells xenografts in nude mice before $(0 \mathrm{~h})$ and 2, 4, 6 and $12 \mathrm{~h}$ after exposure to [(Au0)300-G5.NHAc-(PEG-FA)-mPEG] DENPs (1-4) and [(Au0)300-G5.NHAcmPEG] DENPs (5 and 6) via different admission routes. The tumor areas were labeled with "*". $1 \times 10^{6}$ HeLa cells were subcutaneously injected on the right side of the backs of 4-to 6-week-old male BALB/c nude mice. Approximately 3 weeks after the injection, the mice were then placed in a scanning holder and scanned with a micro-CT imaging system as described in the Materials and Methods. The data shows that treatment with Au DENPs-FI-FA-DTA increases the CT signal intensities in the HeLa cell xenografts, which can be blocked by pretreatment with free FA. These results further demonstrate the roles of the FA moieties in mediating the specific targeting of our nanoparticles. ( 300 $\times 300 \mathrm{DPI})$.

\subsection{Histological studies}

To further verify the uptake of Au DENPs in the targeted cervical cancer cells, tumor xenografts were sliced and stained with silver stains using a silver enhancement kit. As illustrated in Fig 10, the control sample without treatment does not exhibit brown spots. By contrast, all tumor slices from mice injected with either targeted DENPs or non-targeted DENPs via different routes 6 hours after the injections displays numerous dark brown spots in the cytoplasm of the cells; these spots are related to the uptake of AuNPs particles by the cancer cells. Moreover, the $\mathrm{Au}$ density in the staining are consistent with the results from ICP-AES as described earlier, further verifying the specific uptake of the $\mathrm{Au}$ DENPs by cervical cancer cells through different injection sites. Moreover, HE staining of tumor tissue sections from mice in different groups indicates that the cellular uptake of the $\mathrm{Au}$ particles via different administration routes does not influence the morphology of cervical cancer cells.

To explore the cytotoxicity of DENPs in healthy nude mice one month after the intraperitoneal or intravenous injections, HE and silver staining of the major organs of the mice were performed and examined under a light microscope. Similar to the control group with no treatment, the treatment with DENPs particles does not cause any changes in the morphologies of major organs, implying that the injections of DENPs through either intraperitoneal or intravenous routes do not cause any apparent toxicity in mice. In the meantime, the data from silver staining demonstrate that nearly no $\mathrm{Au}$ was observed in all the main organs of mice one month after intraperitoneal or intravenous injections of the Au particles, suggesting that the PEGylated Au DENPs particles are excreted from the mice over time, which is of great importance in terms of their potential applications in targeted CT imaging of human cancers.

\subsection{Biodistribution of Au DENPs-FA nanoparticles}

Determining the biodistribution of the $\mathrm{Au}$ DENPs-FI-FA-DTA is critical for the potential application of the nanoprobes in in vivo targeted CT imaging. Thus, we next conducted ICP-AES to examine the biodistribution of the $\mathrm{Au}$ DENPs-FI-FA-DTA in HeLa cells xenografts and several major organs, including the heart, lung, stomach, liver, intestines, spleen, kidney, testicle, and brain 6 hours after the injection of the 
DENPs particles via intraperitoneal or intravenous routes (Fig 11). Besides its high abundance in the kidneys and tumor, large amounts of elemental $\mathrm{Au}$ were also detected in the RES organs, including the lung, liver and spleen (41). This finding demonstrates that, besides its accumulation in tumor tissues, Au can be excreted mainly via the RES and renal-urinary routes. Further efforts to reduce its capture by RES, as well as detailed pharmacokinetic studies of the $\mathrm{Au}$ DENPs-

FI-FA-DTA particles, should be performed to better understand the mechanisms involved in this process. These data suggest that the $\mathrm{Au}$ particles we developed can escape its clearance from the RES and be specifically taken up by tumor cells through different administration routes, underling the mechanisms by which the nanoparticles can serve as imaging probes for targeted CT imaging of tumors.

Taken together, in this study we synthesized $\mathrm{Au}$ DENPs nanoparticles and evaluated its potential application in the targeted CT imaging of HeLa cancer cells in vitro and in vivo. Our data suggest that HeLa cells could be detected through X-ray attenuation after incubation with $\mathrm{Au}$ in vitro. Additionally, HeLa cell xenograft tumors can be effectively imaged following the intravenous, intraperitoneal, and intratumoral administration of the NPs particles. Furthermore, our findings demonstrated that FA-conjugated Au DSNPs particles can specifically bind to HeLa cells with high levels of FAR expression, whereas the nanoparticles do not cause cytotoxic effects on both cancer and healthy normal cells. There data demonstrated that the Au DSNPs particles we developed in this study are promising nanoprobes for the targeted CT imaging of human cervical cancer. Considering the facile nature of dendrimer nanoparticles and versatility of surface conjugation reactions, a variety of targeted AuNPs nanoparticles may be developed in the future for the targeted CT imaging of a wide range of human cancers.

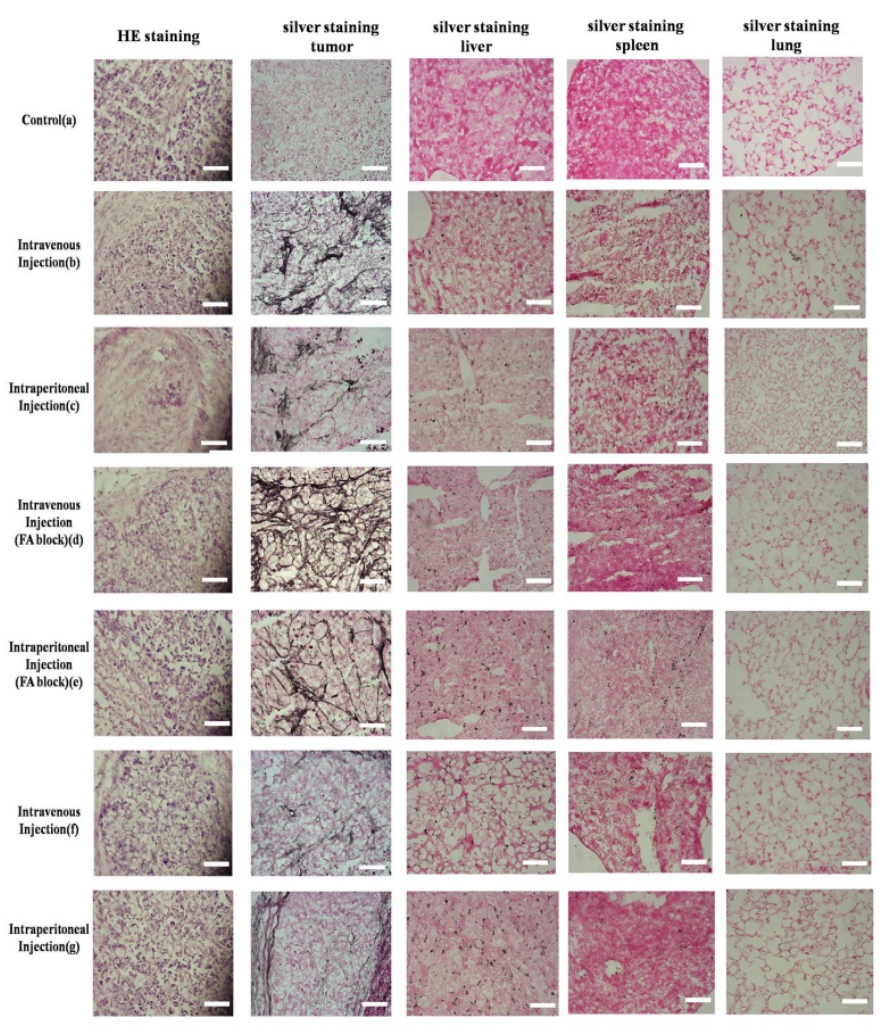

Figure 10. HE and silver staining of the HeLa cells xenograft tumor section, liver, spleen and lung in nude mice before ( $\mathrm{g}$ ) and 6 hours after exposure to [(Au0)300-G5.NHAc-(PEG-FA)-mPEG] DENPs (a-d) and [(Au0)300-G5.NHAc-mPEG] DENPs (e and f) via different admission routes. Scale bar measures 100 $\mu$ m. After the treatment with the nanoparticles, the tissues from the HeLa cells xenograft tumor, liver, spleen and lung in nude mice were fixed with a $0.1 \mathrm{M}$ phosphate buffer containing $4 \%$ paraformaldehyde for $2 \mathrm{~h}$. HE staining was then performed as described in the Materials and Methods. Additionally, the tissues were treated with Lugol's solution and subjected to silver staining with a silver enhancement kit according to the manufacturer's protocols. The morphology of the cells was examined using an optical microscope. Our results demonstrate that numerous dark brown spots can be observed in the cytoplasm of the cells from the tumor slices after injected with either targeted DENPs or non-targeted DENPs via different routes. These results verify the specific uptake of the Au DENPs by cervical cancer cells through different injection sites.Scale bar measures $50 \mu \mathrm{m}(\times 200$ magnification $)(300 \times 300 \mathrm{DPI})$. 


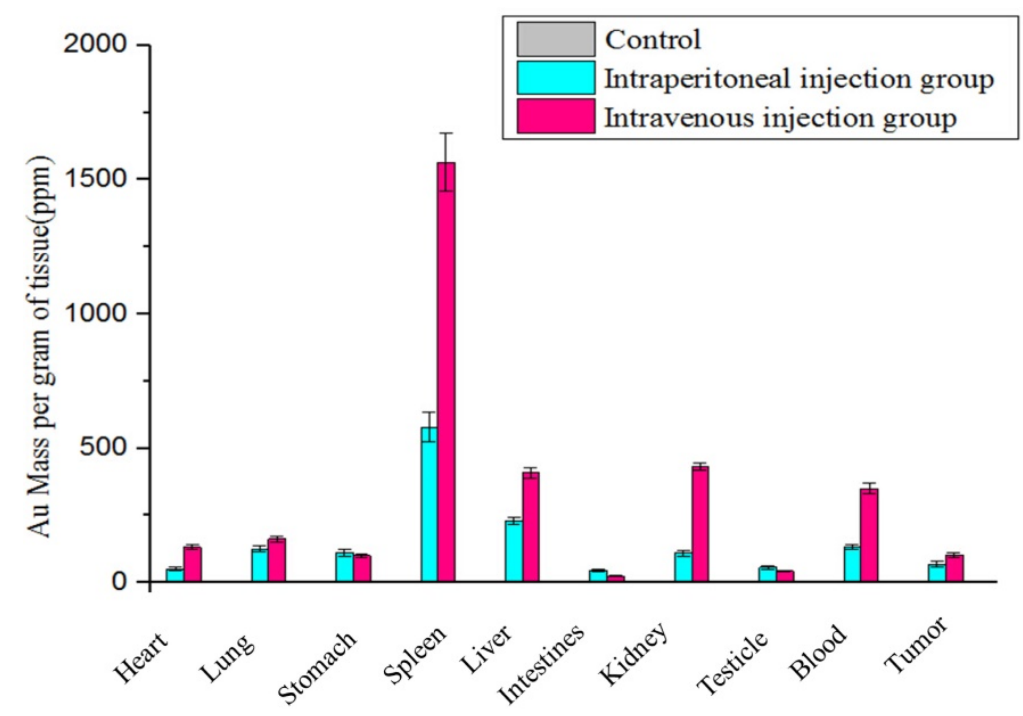

Figure 11. The biodistribution of $\{(\mathrm{Au} 0) 50-\mathrm{G} 5$.NHAc-FA5 $\}$ DENPs nanoparticles in the HeLa cells xenografts and other major organs. 6 hours after the injection of the DENPs via the intraperitoneal and intravenous routes, the mice were sacrificed and the organs of the mice, including the tumor, heart, lung, stomach, spleen, liver, intestines, kidney, testicle, blood and tumor, were harvested, processed into 1-2 mm² pieces and incubated in the aqua regia solution for 4 hours. The Au content in the organs was then measured using ICP-AES. The bar graph shows that large amounts of elemental Au were detected in the kidneys and tumor tissues as well as in the RES organs, including the lung, liver and spleen, suggesting that Au can be excreted mainly via the RES and renal-urinary routes besides its accumulation in tumor tissues.

\section{Acknowledgments}

This research was supported by the National Natural Science Foundation of China (81370423, 81371517, 81601621, and 81401458), the Shanghai JiaoTong University School of Medicine Doctoral Innovation foundation (BXJ201231, for J Qin), and the Fund of Shanghai Sailing Program (grant 15YF1406900).

\section{Competing Interests}

The authors have declared that no competing interest exists.

\section{References}

1. Clifford $G$, Smith J, Plummer $M$, Munoz N, Franceschi S. Human papillomavirus types in invasive cervical cancer worldwide: a meta-analysis. British journal of cancer. 2003;88(1):63-73.

2. Filippova M, Filippov V, Williams VM, Zhang K, Kokoza A, Bashkirova S, et al. Cellular levels of oxidative stress affect the response of cervical cancer cells to chemotherapeutic agents. BioMed research international. 2014;2014.

3. Peer D, Karp JM, Hong S, Farokhzad OC, Margalit R, Langer R. Nanocarriers as an emerging platform for cancer therapy. Nature nanotechnology. 2007;2(12):751-60.

4. Singh M, Singh S, Prasad S, Gambhir I. Nanotechnology in medicine and antibacterial effect of silver nanoparticles. Digest Journal of Nanomaterials and Biostructures. 2008:3(3):115-22.

5. Moghimi SM, Hunter AC, Murray JC. Nanomedicine: current status and future prospects. The FASEB Journal. 2005;19(3):311-30.

6. Choi M-R, Stanton-Maxey KI, Stanley JK, Levin CS, Bardhan R, Akin D, et al A cellular Trojan Horse for delivery of therapeutic nanoparticles into tumors. Nano letters. 2007;7(12):3759-65.

7. Skrabalak SE, Chen J, Au L, Lu X, Li X, Xia Y. Gold nanocages for biomedical applications. Advanced Materials. 2007;19(20):3177-84.

8. Kim D, Park S, Lee JH, Jeong YY, Jon S. Antibiofouling polymer-coated gold nanoparticles as a contrast agent for in vivo $\mathrm{X}$-ray computed tomography imaging. Journal of the American Chemical Society. 2007;129(24):7661-5.

9. Kumar A, Ma H, Zhang X, Huang K, Jin S, Liu J, et al. Gold nanoparticles functionalized with therapeutic and targeted peptides for cancer treatment. Biomaterials. 2012;33(4):1180-9.
10. Peng C, Zheng L, Chen Q, Shen M, Guo R, Wang H, et al. PEGylated dendrimer-entrapped gold nanoparticles for in vivo blood pool and tumor imaging by computed tomography. Biomaterials. 2012;33(4):1107-19.

11. Connor EE, Mwamuka J, Gole A, Murphy CJ, Wyatt MD. Gold nanoparticles are taken up by human cells but do not cause acute cytotoxicity. Small. 2005;1(3):325-7.

12. Maeda $\mathrm{H}, \mathrm{Wu} J$, Sawa $\mathrm{T}$, Matsumura $\mathrm{Y}$, Hori K. Tumor vascular permeability and the EPR effect in macromolecular therapeutics: a review. Journal of controlled release. 2000;65(1):271-84.

13. Patra CR, Bhattacharya R, Mukhopadhyay D, Mukherjee P. Fabrication of gold nanoparticles for targeted therapy in pancreatic cancer. Advanced drug delivery reviews. 2010;62(3):346-61.

14. Hirsjarvi S, Passirani C, Benoit J-P. Passive and active tumour targeting with nanocarriers. Current drug discovery technologies. 2011;8(3):188-96.

15. Yamakawa Y, Ueda M, Nagahata R, Takeuchi K, Asai M. Rapid synthesis of dendrimers based on calix [4] resorcinarenes. Journal of the Chemical Society, Perkin Transactions 1. 1998; 24:4135-40.

16. Esfand R, Tomalia DA. Poly (amidoamine)(PAMAM) dendrimers: from biomimicry to drug delivery and biomedical applications. Drug discovery today. 2001;6(8):427-36.

17. Peng, C.Li KC, Cao XY, Xiao TT, Hong WX, Zheng LF, et al. Facile formation of dendrimer-stabilized gold nanoparticles modified with diatrizoic acid for enhanced computed tomography imaging applications. Nanoscale, 2012. 4(21): 6768-6778

18. Guo R, Wang H, Peng C, Shen M, Pan M, Cao X, et al. X-ray attenuation property of dendrimer-entrapped gold nanoparticles. The Journal of Physical Chemistry C. 2009;114(1):50-6.

19. Guo R, Wang H, Peng C, Shen M, Zheng L, Zhang G, et al. Enhanced X-ray attenuation property of dendrimer-entrapped gold nanoparticles complexed with diatrizoic acid. Journal of Materials Chemistry. 2011;21(13):5120-7.

20. Liu H, Xu Y, Wen S, Zhu J, Zheng L, Shen M, et al. Facile formation of low generation dendrimer-stabilized gold nanoparticles for in vivo $\mathrm{X}$-ray computed tomography imaging applications. Polym Chem. 2013;4:1788-95.

21. Kaminskas LM, Porter CJ. Targeting the lymphatics using dendritic polymers (dendrimers). Advanced drug delivery reviews. 2011;63(10):890-900.

22. Zhu J, Zheng L, Wen S, Tang Y, Shen M, Zhang G, et al. Targeted cancer theranostics using alpha-tocopheryl succinate-conjugated multifunctional dendrimer-entrapped gold nanoparticles. Biomaterials. 2014;35(26):7635-46.

23. Wang H, Zheng L, Peng C, Shen M, Shi X, Zhang G. Folic acid-modified dendrimer-entrapped gold nanoparticles as nanoprobes for targeted CT imaging of human lung adencarcinoma. Biomaterials. 2013;34(2):470-80.

24. Myc A, Majoros IJ, Thomas TP, Baker JR. Dendrimer-based targeted delivery of an apoptotic sensor in cancer cells. Biomacromolecules. 2007;8(1):13-8.

25. Quintana A, Raczka E, Piehler L, Lee I, Myc A, Majoros I, et al. Design and function of a dendrimer-based therapeutic nanodevice targeted to tumor cells through the folate receptor. Pharmaceutical research. 2002;19(9):1310-6.

26. Wang $\mathrm{SH}$, Shi $\mathrm{X}$, Van Antwerp $\mathrm{M}$, Cao $\mathrm{Z}$, Swanson $\mathrm{SD}$, Bi $\mathrm{X}$, et al. Dendrimer-Functionalized Iron Oxide Nanoparticles for Specific Targeting and Imaging of Cancer Cells. Advanced Functional Materials. 2007;17(16):3043-50. 
27. Hong S, Bielinska AU, Mecke A, Keszler B, Beals JL, Shi X, et al. Interaction of poly (amidoamine) dendrimers with supported lipid bilayers and cells: hole formation and the relation to transport. Bioconjugate chemistry. 2004;15(4):774-82.

28. Zheng XT, Chen P, Li CM. Anticancer Efficacy and Subcellular Site of Action Investigated by Real-Time Monitoring of Cellular Responses to Localized Drug Delivery in Single Cells. Small. 2012;8(17):2670-4.

29. Aharon T, Schneider RJ. Selective destabilization of short-lived mRNAs with the granulocyte-macrophage colony-stimulating factor AU-rich 3' noncoding region is mediated by a cotranslational mechanism. Mol Cell Biol. 1993;13(3):1971-80.

30. Shi X, Wang SH, Van Antwerp ME, Chen X, Baker Jr JR. Targeting and detecting cancer cells using spontaneously formed multifunctional dendrimer-stabilized gold nanoparticles. Analyst. 2009;134(7):1373-9.

31. Majoros IJ, Keszler B, Woehler S, Bull T, Baker JR. Acetylation of poly (amidoamine) dendrimers. Macromolecules. 2003;36(15):5526-9.

32. Shi X, Wang S, Meshinchi S, Van Antwerp ME, Bi X, Lee I, et al. Dendrimer-Entrapped Gold Nanoparticles as a Platform for Cancer-Cell Targeting and Imaging. Small. 2007;3(7):1245-52.

33. Shi X, Sun K, Baker Jr JR. Spontaneous formation of functionalized dendrimer-stabilized gold nanoparticles. The Journal of Physical Chemistry C. 2008;112(22):8251-8.

34. Chithrani BD, Ghazani AA, Chan WCW. Determining the size and shape dependence of gold nanoparticle uptake into mammalian cells. Nano letters. 2006;6(4):662-8.

35. Bhumkar DR, Joshi HM, Sastry M, Pokharkar VB. Chitosan reduced gold nanoparticles as novel carriers for transmucosal delivery of insulin. Pharmaceutical research. 2007;24(8):1415-26.

36. Smith J, Martin L. Do cells cycle? Proceedings of the National Academy of Sciences. 1973;70(4):1263-7.

37. Dolbeare F, Gratzner H, Pallavicini M, Gray J. Flow cytometric measurement of total DNA content and incorporated bromodeoxyuridine. Proceedings of the National Academy of Sciences. 1983;80(18):5573-7.

38. Kajstura M, Halicka HD, Pryjma J, Darzynkiewicz Z. Discontinuous fragmentation of nuclear DNA during apoptosis revealed by discrete " sub-G1 " peaks on DNA content histograms. Cytometry Part A. 2007;71(3):125-31.

39. Lesniak W, Bielinska AU, Sun K, Janczak KW, Shi X, Baker JR, et al Silver/dendrimer nanocomposites as biomarkers: fabrication, characterization, in vitro toxicity, and intracellular detection. Nano letters. 2005;5(11):2123-30.

40. Zhang Z, Jia J, Lai Y, Ma Y, Weng J, Sun L. Conjugating folic acid to gold nanoparticles through glutathione for targeting and detecting cancer cells. Bioorganic \& medicinal chemistry. 2010;18(15):5528-34.

41. Yoo J-W, Chambers E, Mitragotri S. Factors that control the circulation time of nanoparticles in blood: challenges, solutions and future prospects. Current pharmaceutical design. 2010;16(21):2298-307. 